\title{
MIXED CLASS TEACHING AS AN EMERGING TREND ACCELERATED BY COVID-19
}

\author{
Jelena Zascerinska ${ }^{1}$, Anastasija Aleksejeva ${ }^{2}$, Mihails Zascerinskis ${ }^{3}$, \\ Olga Gukovica $^{4}$, Ludmila Aleksejeva $^{5}$, Irina Abjalkiene ${ }^{6}$ \\ $1,2,3,4,5,6$ Centre for Education and Innovation Research, Latvia
}

\begin{abstract}
The COVID-19 pandemic has essentially accelerated the pace of the teaching transformation. Mixed (also hyflex) class teaching has become indispensable in medical, engineering, teacher and other fields of education when only online teaching is not enough to ensure the continuity of the instruction. The research aim is to identify scenarios of mixed class teaching underpinning the elaboration of implications for higher education. The present research used both - theoretical and empirical methods. The theoretical methods included the analysis of scientific literature, theoretical modelling, systematisation, synthesis, comparison, and generalisation. The empirical study carried out in June 2021 was exploratory. Data were collected through the analysis of published studies. The collected data were processed via content analysis. The present research allows concluding that teaching has undergone significant changes in different historical periods. The findings of the empirical study facilitate the conclusion on the existence of two scenarios of mixed class teaching, namely HOT (Here or There) and COIL (Collaborative Online International Learning). Both scenarios are oriented to students' learning, teaching in these scenarios is neither segmented nor structured. The novel contribution of the research is revealed in the implications on mixed class teaching for higher education. Future research work was proposed.

Keywords: COVID-19, Educational Process, Hyflex (Hybrid Flexible) Class Teaching, Mixed Class, On-campus Students, Remote Students' Teaching, Teaching Sub-Phases.
\end{abstract}

To cite this article:

Zascerinska, J., Aleksejeva, A., Zascerinskis, M., Gukovica, O., Aleksejeva, L., \& Abjalkiene, I. (2021). Mixed Class Teaching as an Emerging Trend Accelerated by COVID-19. Education. Innovation. Diversity, 2(3), 53-65 DOI: https://doi.org/10.17770/eid2021.2.6720

\section{Introduction}

Since many years, teaching remains an important part of education despite contemporary foci on peer-learning and learning in education and training (Ahrens, Zaščerinska, Lange, \& Aḷeksejeva, 2021).

The COVID-19 pandemic stimulated simultaneous delivery of a face-to-face course to on-campus and remote off-campus students (White, Ramirez, Smith, \& Plonowski, 2010) or, in other words, mixed class teaching, also known as hyflex (hybrid flexible) class teaching (Aleksejeva, Zascerinskis, Abjalkiene, Gukovica, Zascerinska, \& Ahrens, 2021).

Analysis of the existing literature reveals exploratory and qualitative nature and focus of the previously done research (Raes, Detienne, Windey, \& Depaepe, 2020). Mostly, descriptions of students' experiences, the organisational implementation and the technological design were investigated (Raes, Detienne, Windey, \& Depaepe, 2020). Empirical studies have only begun to emerge, and more research is needed into different pedagogical scenarios and their impact on student outcomes (Raes, Detienne, Windey, \& Depaepe, 2020).

The research aim is to employ theoretical and empirical methods for the identification of scenarios of mixed class teaching underpinning the elaboration of implications for higher education.

The present research employs both - theoretical and empirical methods. The theoretical methods include analysis of scientific literature, theoretical modelling, systematisation, synthesis, comparison, and generalisation. The empirical study was exploratory. Data were 
collected through the analysis of published studies. The content analysis for processing the collected data was carried out. The novel contribution of the research is revealed in implications on mixed class teaching for higher education.

\section{Conceptual Framework}

Education is widely recognised to be a process (Ahrens, Zaščerinska, Lange, \& Aḷeksejeva, 2021). This process is broadly defined as the educational process (Zaščerinska, Zaščerinskis, Andreeva, \& Aḷeksejeva, 2013). The other terms of the educational process include educational processes (Smidt, 2015), educational practice(s) (Murphy, 2013), educative process (Judd, Bagley, Kilpatrick, Moore, \& Chassell, 1923), education as process (Creasy, 2018), the process of education (Bruner, 1960), educational technology (Thota, \& Negreiros, 2015), and similar. The educational process is implemented in a certain sequence as depicted in Figure 1: from teaching in Phase 1 through peer-learning in Phase 2 to learning in Phase 3 (Ahrens \& Zaščerinska, 2010, p. 185). The educational process sequentially proceeds (Zaščerinska, 2011, p. 105-106):

- Phase 1 Teaching is aimed at a safe environment for all the learners. In order to provide a safe environment, the essence of constructive social interaction and its organizational regulations are considered by both the teacher and learners. The present phase is organized in a frontal way involving the learners to participate.

- Phase 2 Peer-Learning is designed for the learners' analysis of an open academic problem situation and their search for a solution. The same materials can be prepared for all of the class/group learners. This phase involves the learners to act in peers.

- Phase 3 Learning emphasizes the learners' self-regulation with the. use of assessment of the process and self-evaluation of the results.
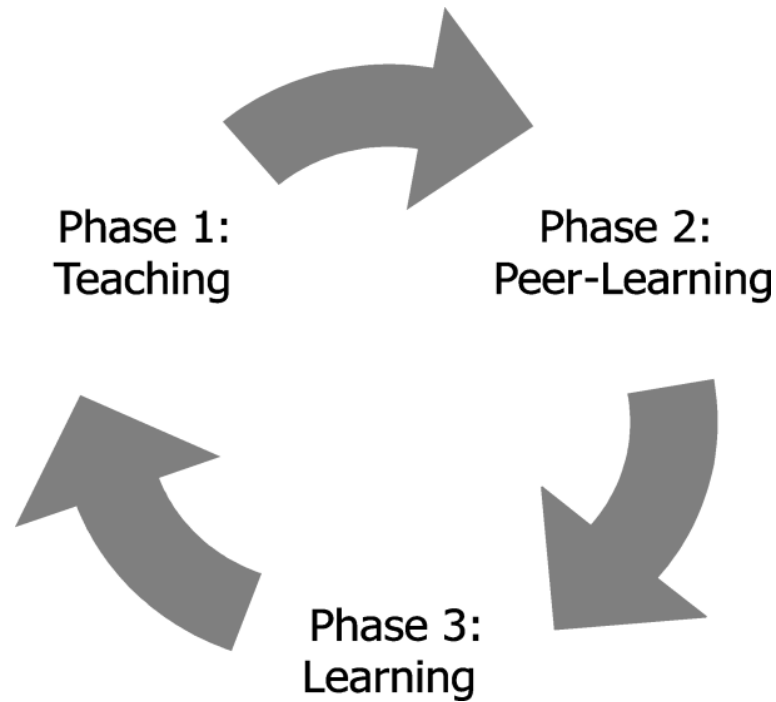

Figure 1 The phases of the educational process (Ahrens \& Zaščerinska, 2010, p. 185)

The present research mainly focuses on teaching. Teaching is the first phase in the educational process (Zaščerinska, 2013). Figure 2 reveals the relationships between education as the macro-environment, educational process as the mezzo-environment, as well as teaching, peer-learning and learning as the micro-environment. 


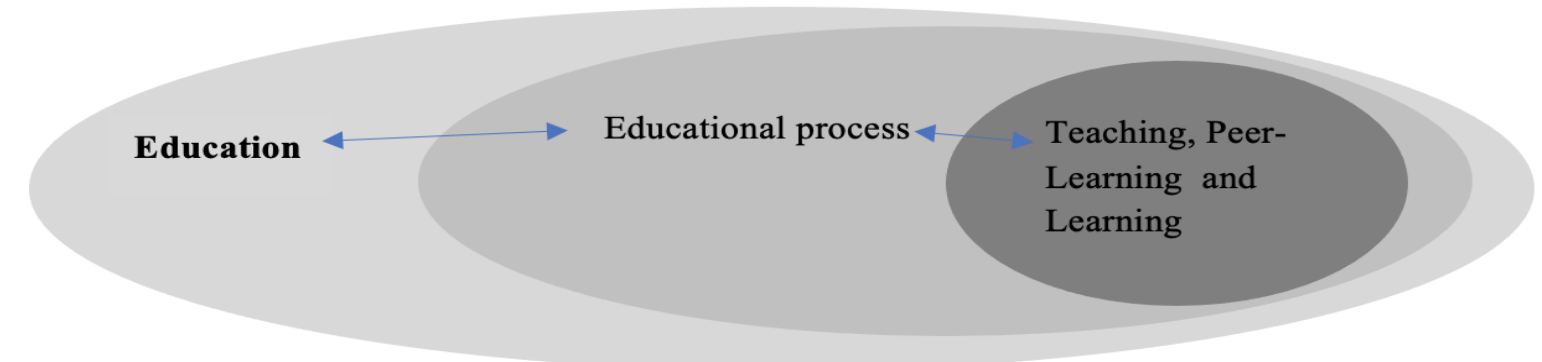

Figure 2 The relationship between education, educational process, teaching, peer-learning and learning (the authors)

Table 1 gives an overview on the teaching development in different historical periods.

Table 1 Teaching development in different historical periods (the authors)

\begin{tabular}{|c|c|c|c|}
\hline $\begin{array}{l}\text { Historical } \\
\text { period }\end{array}$ & $\begin{array}{l}\text { Teaching } \\
\text { definition }\end{array}$ & A short description of teaching & Reference \\
\hline $\begin{array}{l}40 \quad 000 \text { years } \\
\text { ago }\end{array}$ & $\begin{array}{l}\begin{array}{l}\text { Teaching by the } \\
\text { people } \\
\text { teaching) }\end{array} \\
\text { (people }\end{array}$ & $\begin{array}{l}\text { Simple pedagogical views and ideas } \\
\text { that were most fully manifested in } \\
\text { labor activity, traditions, rituals, } \\
\text { customs, games, holidays, oral folk } \\
\text { speech }\end{array}$ & $\begin{array}{l}\text { Amirov, } \\
\text { Kudashkina, \& } \\
\text { Lipatova, 2017, p. } \\
18\end{array}$ \\
\hline $\begin{array}{l}\text { over } 2000 \text { years } \\
\text { ago }\end{array}$ & $\begin{array}{l}\text { Teaching as the } \\
\text { effective strategy } \\
\text { for learning }\end{array}$ & $\begin{array}{l}\text { What kind of learning is desired and } \\
\text { toward what ends by the Greek } \\
\text { philosophers, Socrates ( } 469-399 \\
\text { B.C.), Plato ( } 427-347 \text { B.C.), and } \\
\text { Aristotle ( } 384-322 \text { B.C) }\end{array}$ & $\begin{array}{l}\text { Hammond, } \\
\text { Orcutt, \& Rostin, } \\
\text { 2001, p. } 3\end{array}$ \\
\hline $\begin{array}{l}500 \text { A.D. to } \\
1500 \text { A.D. }\end{array}$ & $\begin{array}{l}\text { Teaching at } \\
\text { religious schools }\end{array}$ & $\begin{array}{l}\text { Transmission-based teaching from the } \\
\text { priest to the people }\end{array}$ & Monroe, 1925 \\
\hline $\begin{array}{l}\text { 15th to the } 17 \text { th } \\
\text { century, The } \\
\text { Renaissance }\end{array}$ & $\begin{array}{l}\text { Teaching for } \\
\text { thinking }\end{array}$ & $\begin{array}{l}\text { For thinking - the effort to understand } \\
\text { ideas and use knowledge for broader } \\
\text { purposes }\end{array}$ & $\begin{array}{l}\text { Hammond, Austin, } \\
\text { Orcutt, \& Rosso, } \\
\text { 2001,p. } 4\end{array}$ \\
\hline $18^{\text {th }}$ century & $\begin{array}{l}\text { Teaching } \\
\text { learning }\end{array}$ & The unity of teaching and learning & $\begin{array}{l}\text { Zakirova, } \\
\text { Grigoryeva, \& \& } \\
\text { Kayumova, 2018, p. } \\
7\end{array}$ \\
\hline $19^{\text {th }}$ century & $\begin{array}{l}\text { Teaching from the } \\
\text { psychological } \\
\text { perspective }\end{array}$ & $\begin{array}{l}\text { Behaviorist vs. cognitive psychology: } \\
\text { the scientific study of learning for } \\
\text { searching the best approach to } \\
\text { teaching }\end{array}$ & $\begin{array}{l}\text { Hammond, } \\
\text { Orcutt, \& } \\
\text { 2001, postin, } 5\end{array}$ \\
\hline $20^{\text {th }}$ century & $\begin{array}{l}\text { Teaching and } \\
\text { peer-learning }\end{array}$ & $\begin{array}{l}\text { Teachers and peers assist learners in } \\
\text { developing new ideas and skills }\end{array}$ & $\begin{array}{l}\text { Vygotsky, } \\
1934 / 1962\end{array}$ \\
\hline \multirow[t]{2}{*}{$21^{\text {st }}$ century } & 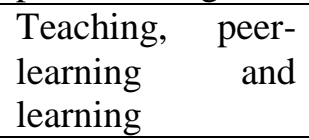 & $\begin{array}{l}\text { The unity of teaching, peer-learning } \\
\text { and learning }\end{array}$ & $\begin{array}{lr}\text { Ahrens } & \& \\
\text { Zaščerinska, } & 2010, \\
\text { p. } 185 & \end{array}$ \\
\hline & $\begin{array}{l}\text { Information and } \\
\text { Communication } \\
\text { Technology } \\
\text { enhanced } \\
\text { teaching }\end{array}$ & $\begin{array}{l}\text { Teaching with the use of Information } \\
\text { and Communication Technology, } \\
\text { digitalized teaching and similar }\end{array}$ & $\begin{array}{l}\text { Zaščerinska, 2009; } \\
\text { Melnikova, } \\
\text { Grünwald, Ahrens, } \\
\text { Pfaffenberger, \& } \\
\text { Zaščerinska, 2017 }\end{array}$ \\
\hline $\begin{array}{l}\text { The COVID-19 } \\
\text { pandemic in the } \\
21^{\text {st }} \text { century }\end{array}$ & $\begin{array}{l}\text { Mixed } \\
\text { teaching }\end{array}$ & $\begin{array}{l}\text { Simultaneous teaching of a class of } \\
\text { both on-campus and remote learners }\end{array}$ & $\begin{array}{l}\text { White, Ramirez, } \\
\text { Smith, \& } \\
\text { Plonowski, } 2010\end{array}$ \\
\hline
\end{tabular}


The COVID-19 pandemic has essentially accelerated the pace of the transformation of the educational process (Ahrens, \& Zascerinska, 2020). Almost overnight, the pandemic has shifted the delivery of education to only online teaching (Ahrens, Zascerinska, Bhati, Zascerinskis, Aleksejeva, 2021) done from home. With warnings of the next COVID-19 wave and other impending pandemics, universities need to be prepared to deliver courses in alternative ways to ensure continuity of instruction (White, Ramirez, Smith, \& Plonowski, 2010). It should be pointed that not all teaching can be done fully online. For example, the shift to online platform poses serious challenges to medical education (Jiang et al, 2020). Expressly, most medical schools set students in physical settings for 1-3 years where their knowledge foundations are built; students' physical presence in both inpatient and outpatient settings has been a successful practice of early clinical immersion experiences and the clerkship curriculum (Jiang et al, 2020). The second half of medical school education requires students to participate in clinical rotations, sub-internships, and/or research projects (Jiang et al, 2020). The same refers to many other educational fields. Among many, there is teacher education, engineering education, maritime education, and others, too.

Figure 3 illustrates a simultaneous delivery of a face-to-face course to on-campus and remote off-campus students (White, Ramirez, Smith, \& Plonowski, 2010) or, in other words, mixed class teaching.

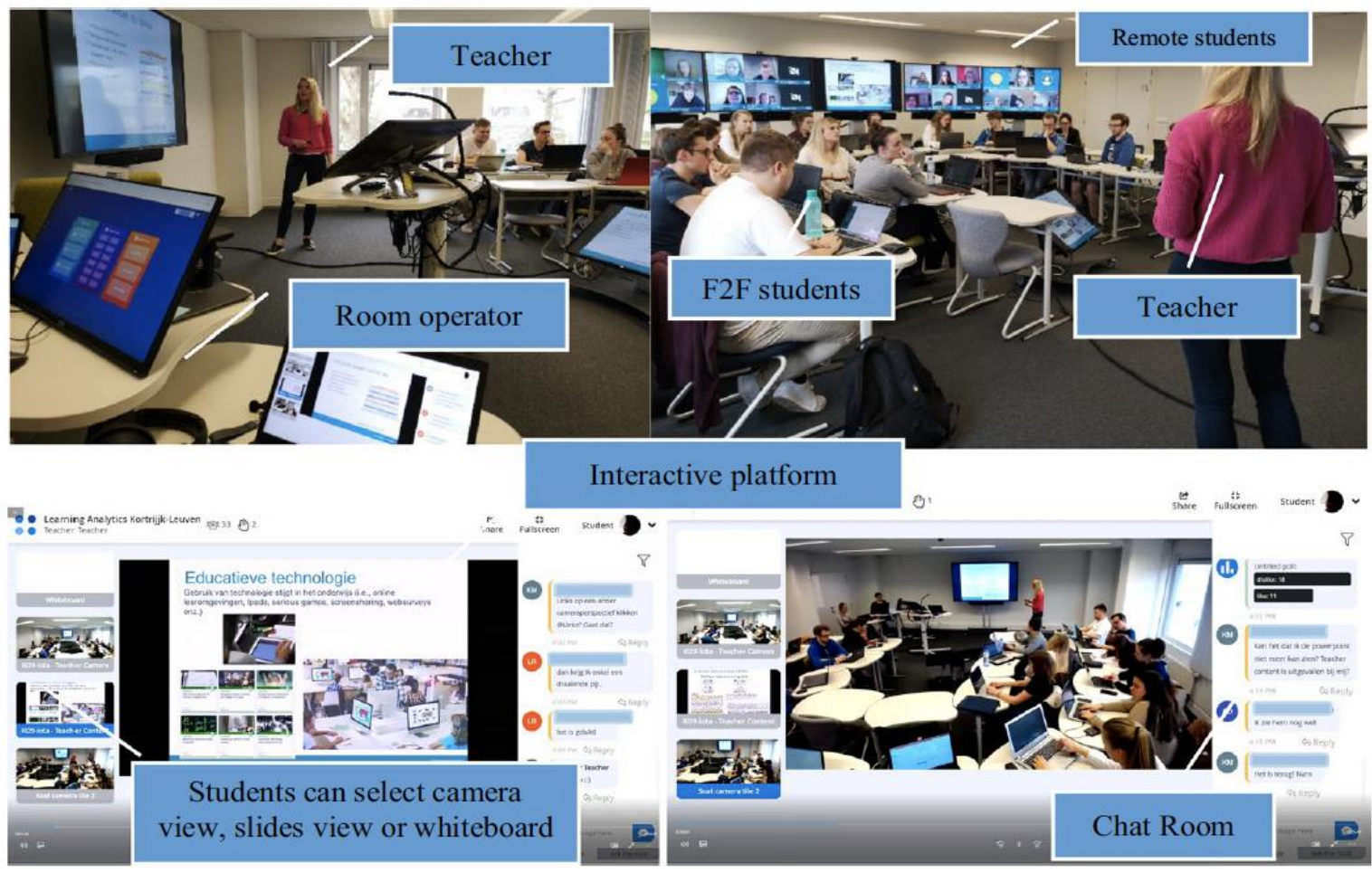

Figure 3 Mixed class including both on-campus (F2F) and remote individual students (upper pictures) and the platform visible for the students (lower pictures)

(Raes, Detienne, Windey, \& Depaepe, 2020)

For comparative purposes, Table 2 demonstrates the differences in the use of the selected terms containing "mixed", "class" and "teaching" and similar terms. 
Table 2 Use of selected terms containing "mixed", "class" and "teaching”(the authors)

\begin{tabular}{|c|c|c|}
\hline Term & Term's meaning & Reference \\
\hline Mixed teaching mode & The mix of online and offline teaching & Xie, 2020 \\
\cline { 1 - 2 } Hybrid teaching mode & & Sun, 2020 \\
\cline { 1 - 1 } $\begin{array}{c}\text { Blended method } \\
\text { classes }\end{array}$ & Students with mixed abilities in a class & Setyawan, 2019 \\
\cline { 1 - 1 } $\begin{array}{c}\text { Teaching mixed ability } \\
\text { Teaching of a mixed } \\
\text { aged / level class }\end{array}$ & $\begin{array}{c}\text { Students of different ages / levels in a } \\
\text { class }\end{array}$ & Smit \& Engeli, 2015 \\
\hline Mixed classroom & $\begin{array}{c}\text { A class environment in a formal } \\
\text { education setting that includes both } \\
\text { Heritage-Learners (HL) and second- } \\
\text { language learners (L2) }\end{array}$ & Morgan, 2017 \\
\hline $\begin{array}{c}\text { Mixed (also known as } \\
\text { hyflex) class teaching }\end{array}$ & $\begin{array}{c}\text { Teaching as part of the educational } \\
\text { process in formal education settings that } \\
\text { is simultaneously addressed to both }- \\
\text { on-campus and remote learners }\end{array}$ & $\begin{array}{c}\text { Aleksejeva, Zascerinskis, } \\
\text { Abjalkiene, Gukovica, } \\
\text { Zascerinska, \& Ahrens, } \\
\text { 2021 }\end{array}$ \\
\hline
\end{tabular}

By a scenario, an approach to assess the future is meant (Sardesai, Stute, \& Kamphues, 2021). It should be noted that approach means a set of theoretical principles (Karapetjana, 2008). A principle is defined as a shared combination of beliefs and assumptions that determine researchers' attitude to the world, their behaviour's norms and activities (Zaščerinska, Ahrens, $\&$ Bassus, 2015). Also, a principle is a condition of activity (Belickis et al., 2000). A condition means a circumstance from which the implementation of a process, process or activity depends (Belickis et al., 2000). In the present research, mixed class teaching depends on the interrelationships between the teacher and learners. For the purposes of the present research, the use of the theoretical methods applied to the work of Sardesai, Stute, and Kamphues (Sardesai, Stute, \& Kamphues, 2021), allows the authors of this contribution to define a pedagogical scenario as the description of an educational situation (environment) casually inter-related with the dynamic process of teaching. It should be pointed that a pedagogical scenario focuses on the creation of a coherent process that is adjusted to the learners' needs (Zogla, 2018). Teachers and learners follow different aims and motives, use different background knowledge and tools, and still their attempts have to be met (Zogla, 2018). This "joint venture" allows for transitions from a normative to a learner learning-centred process with the learners' meaningful participation in creating, conducting and evaluating the process where the learner has to achieve; that is leading to learners' autonomy in learning and development, as well as to teachers', learners', and other stakeholders' overcoming the growing complexity and transferring their way of thinking (Zogla, 2018). Educational situation (environment) is based on social interactions (Ahrens, Foerster, Zaščerinska, \& Wasser, 2020). By interaction, obvious or non-obvious influence on each other in the process of implementing a joint activity (Nikiforovs, 1994) is understood.

The normative scenario focusing on "How can a specific goal be achieved?" (Boerjeson, Hoejer, Dreborg, Ekvall, \&. Finnveden, 2006) will be considered in the present work.

The overall goal of education is the enhancement of learner's experience, namely knowledge, skills and attitude (Ahrens, Zaščerinska, Hariharan, \& Andreeva, 2016). The educational process is discussed to be effective to reach this goal (Hariharan, Zaščerinska, \& Zaščerinskis, 2014).

The educational process is conventionally organized as a lecture, class, or lesson in education (Zaščerinska, 2013). In its turn, class is based on the system of learners' groups 
(Zaščerinska, 2013). Organization of teaching as part of the educational process depends on the class's structure (Zaščerinska, 2013):

- if teaching is the only form within the class, the organization of mixed class teaching coincides with the lecture's structure,

- if mixed class teaching does not coincide with the class's structure, the class is part of teaching.

In the present research, the organization of teaching does and does not coincide with the class structure (Zaščerinska, 2013). It depends on a number of lectures in the semester, learners' age, learners' level of education, etc. Hence, teaching is defined as a class component and a certain system with its own structure (Zaščerinska, 2013).

Teaching as the $1^{\text {st }}$ phase in the educational process has a particular significance as teaching facilitates teachers' and learners' creation of new products, new patents, new entrepreneurial activities and new jobs (Ahrens et al, 2021).

Teaching in formal education is defined as a purposefully organized process of teacher's sharing experience (knowledge, skills and attitudes) with learners (Zaščerinska \& Ahrens, 2013). Teaching in Phase 1 was differentiated into two sub-phases (Zaščerinska, 2013): Teaching in Phase 1.1. and Teaching with the elements of peer-learning in Phase 1.2. as illustrated in Figure 4.

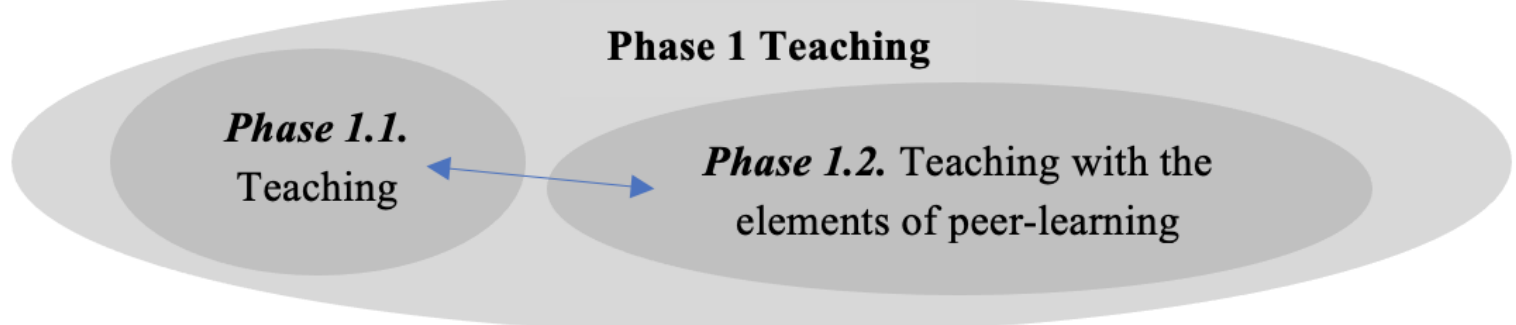

Figure 4 The relationship between teaching and its two sub-phases (the authors)

\section{Methodology}

Methodology is defined as a system of principles, practices, and procedures applied to any specific branch of knowledge (Karapetjana, 2008). The course of the implementation of the empirical study shows how the steps of the process are related following a logical chain.

The empirical study was enabled by the research question: How to organise mixed class teaching? The purpose of the study was to analyse mixed class teaching experiences. It should be noted that experiences at different universities follow different traditions, approaches, cultural contexts (Zogla \& Lubkina, 2020).

The empirical study was carried out in June 2021. The empirical study was exploratory. Here the exploratory relates to being open at the outset of the study (Ahrens, Zascerinska, Bhati, Zascerinskis, \& Aleksejeva, 2021). The exploratory methodology was chosen (Ahrens, Foerster, Zaščerinska, Wasser, 2020), as

- on the one hand, the addressed phenomenon, namely mixed class teaching, requires more research into different pedagogical scenarios and their impact on student outcomes (Raes, Detienne, Windey, \& Depaepe, 2020), and

- on the other hand, an exploratory study is characterised by a high degree of flexibility as well as a lack of formal structure and aims to identify the boundaries of the social environment, namely mixed class teaching, based on social interactions. 
Data were collected through the analysis of published studies on the theme of the present research, namely mixed class teaching. Data were collected through reviewing, analysing, comparing and synthesising experiences from observations and interviews as well as in the literature on the theme in "an integrated way such that new frameworks and perspectives on the topic are generated" (Torraco, 2005, p 356). The content analysis for processing the collected data was carried out. The content analysis was differentiated into structuring content analysis and summarising content analysis (Mayring, 2014). Structuring content analysis means data categorising based on the previously defined criteria (Budde, 2005). Summarising content analysis tends to preserve the essential contents in a manageable short text (Mayring, 2004).

The processed data were interpreted. The researcher is the interpreter (Ahrens, Purvinis, Zaščerinska, Micevičiene, \& Tautkus, 2018). The interpreter reveals his/her interest in a phenomenon (Zascerinska, Aleksejeva, Zascerinskis, Gukovica, \& Aleksejeva, 2020) as well as practical interest in the research question (Cohen, Manion, \& Morrison, 2003). The interpretive paradigm is aimed at analysing the social construction of the meaningful reality (Zascerinska, Aleksejeva, Zascerinskis, Gukovica, \& Aleksejeva, 2020). Meanings emerge from the interpretation (Zascerinska, Aleksejeva, Zascerinskis, Gukovica, \& Aleksejeva, 2020).

Figure 5 highlights the key steps of the empirical study and the sequence of their implementation.

\section{Figure 5 The key steps of the empirical study and the sequence of their implementation} (the authors)
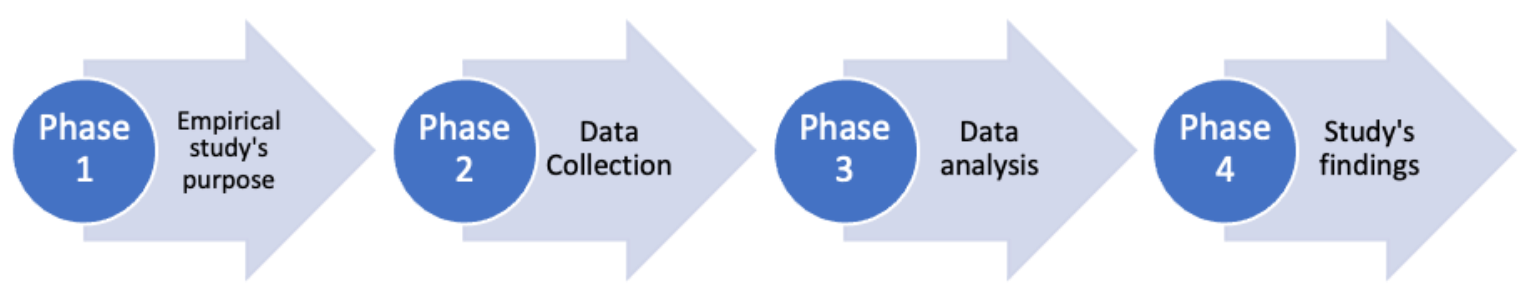

\section{Results of the Empirical Study}

The analysis of the published studies reveals the comparison of two scenarios, namely the Remote Classroom and the Hybrid Virtual Classroom (Raes, Detienne, Windey, \& Depaepe, 2020) as displayed in Figure 6.

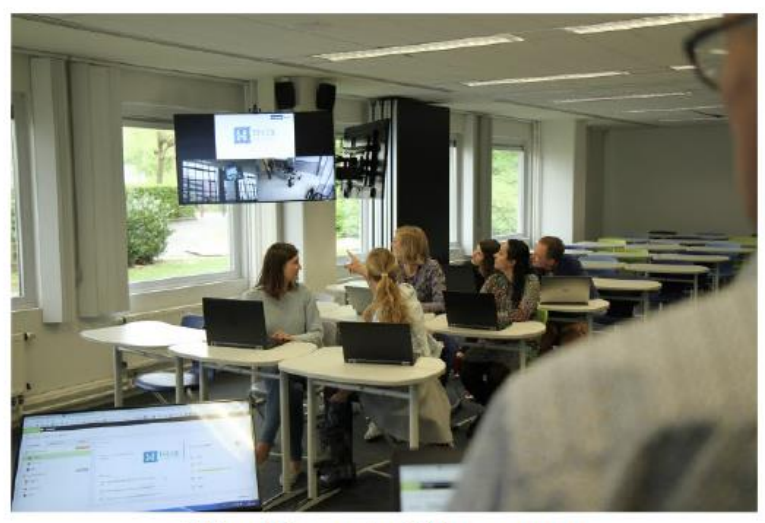

The Remote Classroom

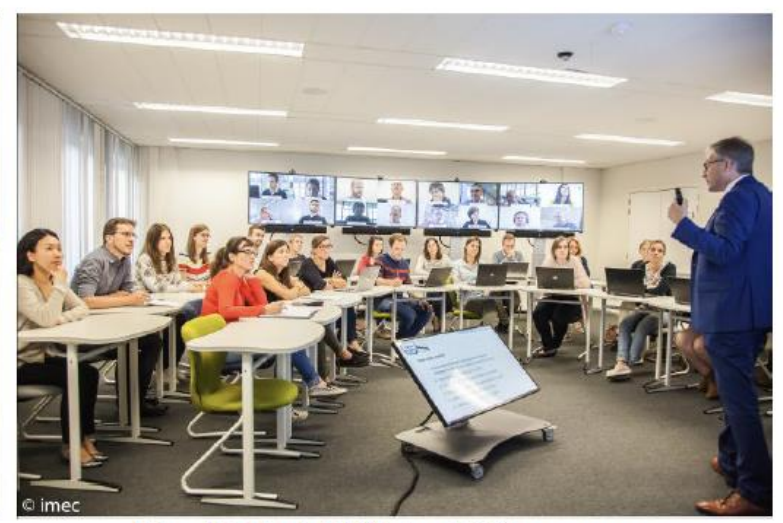

The Hybrid Virtual Classroom

Figure 6 Two models of synchronous hybrid learning

(Raes, Detienne, Windey, \& Depaepe, 2020) 
The picture on the left in Figure 6 depicts what is called the Remote Classroom, whereas the picture on the right depicts the Hybrid Virtual Classroom (Raes, Detienne, Windey, \& Depaepe, 2020). Both learning settings have in common that both on-site or 'here' students and remote or 'there' students are simultaneously included (Raes, Detienne, Windey, \& Depaepe, 2020). This kind of learning and instruction is also framed as Here or There (HOT) instruction (Zydney, McKimm, Lindberg, \& Schmidt, 2019). The difference between the Remote and the Hybrid Virtual Classroom involves the location where students follow the lecture or class (Raes, Detienne, Windey, \& Depaepe, 2020). In the Remote Classroom setting, one group follows the course on campus and another group follows the course synchronously from another campus (the remote location and students are displayed on the screen depicted in the left corner of Figure 6) (Szeto \& Cheng 2016). In the Hybrid Virtual Classroom, one group follows the course on campus and simultaneously individuals follow the course remotely from the location of their choice (Butz, Stupnisky, Pekrun, Jensen, \& Harsell, 2016). This method of teaching offers even more flexibility because it gives learners, as well as students who are, for example, abroad or ill for a longer period of time, the opportunity to participate in the actual lesson and interact at a distance with all students and the teacher from a place of their own choice (Raes, Detienne, Windey, \& Depaepe, 2020).

Another scenario received the name Collaborative Online International Learning (COIL) (Ahrens et al, 2021). COIL connects students and professors in different countries for collaborative projects and discussions as part of their coursework. COIL Collaborations between students and professors provide meaningful, significant opportunities for global experiences built into the programs of study. COIL enhances intercultural student interaction through proven approaches to meaningful online engagement, while providing universities a cost-effective way to ensure that their students are globally engaged. COIL offers a creative, relevant, accessible way of engaging in international teaching and learning (Ahrens et al, 2021). Partners working on COIL programmes can share content and methodology, in mutually beneficial ways (Ahrens et al, 2021). Collaboration of students from a university in the USA and a partner university in South Africa served as the COIL illustration (Ahrens et al, 2021).

\section{Empirical Study's Findings}

The structuring content analysis of the data collected within the present empirical study allows identifying the scenarios of mixed class teaching reflected in Table 3.

Table 3 Scenarios of mixed class teaching (the authors)

\begin{tabular}{|l|l|l|}
\hline \multicolumn{1}{|c|}{ Scenario } & \multicolumn{1}{|c|}{ Sub-scenario } & \multicolumn{1}{c|}{ A short description of the scenario } \\
\hline $\begin{array}{l}\text { HOT } \\
\text { (Here or There) }\end{array}$ & $\begin{array}{l}\text { Remote } \\
\text { Classroom }\end{array}$ & $\begin{array}{l}\text { One group follows the course on campus and another } \\
\text { group follows the course synchronously from another } \\
\text { campus }\end{array}$ \\
\cline { 2 - 3 } & $\begin{array}{l}\text { Hybrid Virtual } \\
\text { Classroom }\end{array}$ & $\begin{array}{l}\text { One group follows the course on campus and } \\
\text { simultaneously individuals follow the course remotely } \\
\text { from the location of their choice }\end{array}$ \\
\hline $\begin{array}{l}\text { COIL (Collaborative } \\
\text { Online International } \\
\text { Learning) }\end{array}$ & $\begin{array}{l}\text { Students and professors in different countries are } \\
\text { connected for collaborative projects and discussions as } \\
\text { part of their coursework }\end{array}$ \\
\hline
\end{tabular}

Table 4 highlights the differences between the scenarios of mixed class teaching.

The structuring content analysis of both scenarios - HOT and COIL - does not allow segmenting the organisation of teaching. In the HOT scenario, a group follows the course (Szeto \& Cheng 2016; Butz, Stupnisky, Pekrun, Jensen, \& Harsell, 2016), while the COIL scenario 
puts the emphasis on students' learning as it is highlighted in the name of the scenario. Consequently, both scenarios are aimed at students' learning.

Table 4 Scenarios of mixed class teaching (the authors)

\begin{tabular}{|c|c|c|c|c|}
\hline \multirow[b]{2}{*}{ Scenario } & \multirow{2}{*}{$\begin{array}{c}\text { Sub- } \\
\text { scenario }\end{array}$} & \multicolumn{3}{|c|}{ Mixed class teaching components } \\
\hline & & Teacher & Students & $\begin{array}{l}\text { Language of } \\
\text { instruction }\end{array}$ \\
\hline \multirow[t]{2}{*}{$\begin{array}{l}\text { HOT } \\
\text { (Here or There) }\end{array}$} & $\begin{array}{l}\text { Remote } \\
\text { Classroom }\end{array}$ & $\begin{array}{l}\text { One teacher in } \\
\text { one of the } \\
\text { campus classes }\end{array}$ & $\begin{array}{l}2 \text { groups of students } \\
\text { from } 2 \text { different } \\
\text { locations }\end{array}$ & $\begin{array}{l}\text { One official } \\
\text { language (used by } \\
\text { the study } \\
\text { programme) for the } \\
\text { teacher and learners }\end{array}$ \\
\hline & $\begin{array}{l}\text { Hybrid } \\
\text { Virtual } \\
\text { Classroom }\end{array}$ & $\begin{array}{l}\text { One teacher in } \\
\text { the campus } \\
\text { class }\end{array}$ & $\begin{array}{l}\text { One group of students } \\
\text { in the campus class, } \\
\text { the others remotely } \\
\text { from the location of } \\
\text { their choice }\end{array}$ & $\begin{array}{l}\text { One official } \\
\text { language (used by } \\
\text { the study } \\
\text { programme) for the } \\
\text { teacher and learners }\end{array}$ \\
\hline $\begin{array}{l}\text { COIL } \\
\text { (Collaborative } \\
\text { Online } \\
\text { International } \\
\text { Learning) }\end{array}$ & & $\begin{array}{l}\text { A couple of } \\
\text { teachers from } \\
\text { different } \\
\text { countries }\end{array}$ & $\begin{array}{l}\text { Students are from at } \\
\text { least } 2 \text { countries, each } \\
\text { of } 2 \text { students' groups } \\
\text { is in the campus class, } \\
\text { these } 2 \text { students' } \\
\text { groups are connected } \\
\text { via the Internet. }\end{array}$ & $\begin{array}{l}\text { An international } \\
\text { language is used for } \\
\text { both teachers' and } \\
\text { students' } \\
\text { communication in } \\
\text { the COIL class }\end{array}$ \\
\hline
\end{tabular}

The summarizing content analysis results in the finding that in both scenarios (HOT and COIL) social interactions between the teacher and students as the basis of mixed class teaching are not structured.

\section{Conclusions}

The theoretical findings of the present research allow concluding that teaching has undergone significant changes in different historical periods. Another conclusion based on the concepts' comparative analysis is drawn on the differences in the use of the selected terms containing "mixed", "class" and "teaching" and similar terms.

The findings of the empirical study facilitate the conclusion on the existence of two scenarios of mixed class teaching, namely HOT and COIL. Both scenarios are oriented to students' learning, teaching in these scenarios is not segmented and structured. The structure of mixed class teaching is to be based on social interactions between the teacher and students, namely, two sub-phases of teaching.

Implications for higher education imply that mixed class teaching is part of the educational process. The contemporary emphasis on peer-learning and/or learning in the modern education has to be shifted to the consideration of the educational process as a whole: the educational process is composed of the defined phases, namely teaching, peer-learning and learning. These three phases of the educational process, namely teaching, peer-learning and learning, proceed in a certain sequence: from teaching through peer-learning to learning. Teaching is the first phase in the educational process that increases the importance of the implementation of teaching within the whole educational process. In mixed class teaching, the inter-relationship or, in other words, social interaction between the teacher and learners is structured: teaching consists of two sub-phases, namely teaching and teaching with the elements of peer-learning. 
The present research has some limitations. A limitation is the theoretical interconnections between mixed class teaching and scenarios. Another limitation is that the data were collected through the analysis of published studies on the theme of the present research, namely mixed class teaching. Also, the methods of data processing, namely the structuring content analysis and the summarising content analysis, serve as a limiting parameter in this research.

Future work will be aimed at expanding the theoretical interconnections of the present research, namely mixed class teaching and scenarios. Discovery of other scenarios of mixed class teaching will be continued. Modelling of mixed class teaching is proposed, too. Also, the search for methods of data collection and processing will be widened. Empirical studies focused on the analysis of mixed class teaching implemented in two sub-phases, namely teaching and teaching with elements of peer-learning, will be carried out. Comparative studies of different countries are of great research interest.

\section{Acknowledgement}

The presented work has been carried out within the Project NPHZ-2021/10050 "STEM COIL for Greener Sustainable Ecosystems: Igniting Global Classrooms" supported by Nordplus Horizontal 2021.

\section{References}

Ahrens, A., \& Zaščerinska, J. (2010). Social dimension of Web 2.0 in Student Teacher Professional Development. In I. Žogla (Ed.), Proceedings of Association for Teacher Education in Europe Spring Conference 2010 Teacher of the 21st Century: Quality Education for Quality Teaching, Riga, Latvia: Uiversity of Latvia, 7-8 May, 2010: 179186.

Ahrens, A., Bhati, P. P., Leshchenko, A., Zaščerinska, J., Gukovica, O., Zascerinskis, M., \& Aleksejeva, A. (2021). Comparative Studies on Inclusive Digital Teaching in Higher Education in Light of COVID-19. In P. Ordóñez de Pablos, M. Almunawar, K. Chui, \& M. Kaliannan (Ed.), Handbook of Research on Analyzing IT Opportunities for Inclusive Digital Learning (pp. 18-45). IGI Global. http://doi:10.4018/978-1-7998-7184-2.ch002

Ahrens, A., Foerster, M., Zaščerinska, J., \& Wasser, I. (2020). European Accreditation Agency's View on Kazakhstan's Engineering and Information Technology Higher Education. Society. Integration. Education. Proceedings of the International Scientific Conference. Volume V, 15-25. http://dx.doi.org/10.17770/sie2020vol1.4861.

Ahrens, A., Purvinis, O., Zaščerinska, J., Micevičienè, D., \& Tautkus, A. (2018). Burstiness Management for Smart, Sustainable and Inclusive Growth: Emerging Research and Opportunities. IGI Global. DOI: 10.4018/978-1-5225-5442-4.

Ahrens, A. \& Zascerinska, J. (2020). Post-COVID-19 University Governance in Germany. Education Reform: Education Content Research and Implementation Problems. Volume 2 (2020), pp. 7-16. Rezekne: Rezekne Academy of Technologies. DOI: $10.17770 /$ er2020.2.5336

Ahrens, A., Zascerinska, J., Bhati, P.B., Zascerinskis, M., \& Aleksejeva, A. (2021). Comparative Studies of COVID-19 Impact on Students' Views on Digital Higher Education. Society. Integration. Education. Proceedings of the International Scientific Conference. Volume V, 17-29. https://doi.org/10.17770/sie2021vol5.6277.

Ahrens, A., Zaščerinska, J., Hariharan, R., Andreeva, N. (2016). Educators' Opinion on Webinars in Higher Education. Proceedings of the International Scientifical Conference Society, Integration, Education, Volume 1 Higher Education Pedagogy, 15-27. DOI: http://dx.doi.org/10.17770/sie2016vol1.1488. 
Ahrens, A., Zaščerinska, J., Lange, C., \& Aḷeksejeva, L. (2021). A Comparative Analysis of Processes of Conceptual Change for the Enhancement of Implementation of Green Energy Education and Training. International Journal of Information and Education Technology (IJIET) vol. 11, no. 1, pp. 47-51, 2021. ISSN: 2010-3689. doi: 10.18178/ijiet.2021.11.1.1488.

Aleksejeva, A., Zascerinskis, M., Abjalkiene, I., Gukovica, O., Zascerinska, J., \& Ahrens, A. (2021). Teaching a HyFlex Class: Scenario Design. XX-All Russian Scientific and Practical Conference for Young Educational Researchers "Research That Improves Education" by Russian Educational Research Association Moscow State University of Psychology and Education. Online, 28-29 October 2021. https://myeduconf.ru

Amirov, A.F., Kudashkina, O.V., \& Lipatova, E.E. (2017). Fundamentals of Pedagogy and Teaching Methods: Study Guide. Retrieved from http://library.bashgmu.ru/elibdoc/elib663.pdf .

Beḷickis, I., Blūma, D., Koķe, T., Markus, D., Skujiņa, V., \& Šalme, A. (2000). Pedagogijias terminu skaidrojošā vārdnīca. Termini latviešu, angḷu, vācu, krievu valodā. Rīga: "Zvaigzne ABC".

Boerjeson L, Hoejer M, Dreborg K-H, Ekvall T, \& Finnveden G (2006) Scenario types and techniques: towards a user's guide. Future, 38, 723-739.

Bruner, J. S. (1960). The process of education. Harvard University Press.

Budde, R. (2005). Mexican and Central American L.A. Garment Workers: Globalized Industries and their economic constraints. LIT Verlag Münster.

Butz, N. T., Stupnisky, R. H., Pekrun, R., Jensen, J. L., \& Harsell, D. M. (2016). The Impact of emotions on student achievement in synchronous hybrid business and public administration programs: A longitudinal test of control-value theory. Decision Sciences Journal of Innovative Education, 14(4), 441-474. Retrieved from https://www.learntechlib.org/p/194958/

Cohen, L., Manion, L., \& Morrsion, K. (2003). Research Methods in Education. London and New York: Routledge/Falmer Taylor \& Francis Group.

Creasy, R. (2018). Education as a Process: Assessment, Outcomes and Achievement. In: The Taming of Education. Palgrave Macmillan, Cham. https://doi.org/10.1007/978-3-319$\underline{62247-7 \quad 6}$

Djurayeva, Y.A. (2021). Teaching Mixed-Ability Student in Classroom. Academic Research in Educational Sciences, Volume 2, Issue 2. DOI: 10.24411/2181-1385-2021-00301

Hammond, L.-D., Austin, K., Orcutt, S., \& Rosso, J. (2001). How People Learn: Introduction into Learning Theories. Stanford University School of Education. Retrieved from https://web.stanford.edu/class/ed269/hplintrochapter.pdf.

Hariharan, R., Zaščerinska, J., \& Zaščerinskis, M. (2014). A Comparative Study of Criteria of Quality of Educational Process in Teacher Education in India and Latvia. The Proceedings of Riga Teacher Training and Educational Management Academy's 9th International Young Scientist Conference, 38-46.

Jiang, Z., Wu, H., Cheng, H., Wang, W., Xie, A’Na \& Fitzgerald, Sarah Rose (2021). Twelve tips for teaching medical students online under COVID-19. Medical Education Online, 26, 1, DOI: 10.1080/10872981.2020.1854066

Judd, C.H., Bagley, W.C., Kilpatrick, W.H., Moore, E.C., \& Chassell, J.O. (1923). What is the Educative Process? Religious Education, 18, 1, 33-51.

https://doi.org/10.1080/0034408230180105

Karapetjana, I. (2008). English for Specific Purposes Teaching Methodology. Riga: Akadēmiskais apgāds.

Mayring, P. (2004). Qualitative Content Analysis. In: U. Flick, E. Von Kardoff and I. Steinke (Eds), A Companion to Qualitative Research, 266-269. SAGE. 
Mayring, P. (2014). Qualitative Content Analysis: theoretical foundation, basic procedures and software solution. Klagenfurt: Social Science Open Access Repository. Retrieved from https://www.psychopen.eu/fileadmin/user_upload/books/mayring/ssoar-2014-mayringQualitative_content_analysis_theoretical_foundation.pdf

Melnikova, J., Grünwald, N., Ahrens, A., Pfaffenberger, K., \& Zaščerinska, J. (2017). The Search for an Approach to Develop Educators' Digital Teaching Competence. Andragogika, 1 (Volume 8), 34-44. http://dx.doi.org/10.15181/andragogy.v6i0.1213 .

Monroe, P. (1925). A Text-book in the history of education. New York, NY: MacMillan Company.

Morgan, B. (2017). Bridging the L1-L2 Divide: Learner-Centered Instruction in the Heritage/L2 Spanish Classroom. In: Jared Keengwe (University of North Dakota, USA) Handbook of Research on Promoting Cross-Cultural Competence and Social Justice in Teacher Education, pp. 270-286. |Pages: 17. DOI: 10.4018/978-1-5225-0897-7.ch014 .

Murphy, A. (2013). Open educational practices in higher education: institutional adoption and challenges. Distance Education, 34, 2, 201-217. https://doi.org/10.1080/01587919.2013.793641

N̦ikiforovs, O. (1994). Lomu mijiedarbības sistēma „Skolotājs-skolēns” ietekme uz skolēnu tuvākās attīstības zonas kognitīvajiem komponentiem [Influence of role interaction system ,"Teacher-pupil” on cognitive elements of pupil's zone of proximal development]. $\mathrm{PhD}$ Thesis. University of Latvia, Riga, Latvia (in Latvian).

Raes, A., Detienne, L., Windey, I., \& Depaepe, F. (2020). A systematic literature review on synchronous hybrid learning: gaps identified. Learning Environ Res 23, 269-290. https://doi.org/10.1007/s10984-019-09303-z.

Sardesai, S., Stute, M., \& Kamphues, J. (2021) A Methodology for Future Scenario Planning. In: Fornasiero, R., Sardesai, S., Barros ,A.C., Matopoulos A. (eds) Next Generation Supply Chains. Lecture Notes in Management and Industrial Engineering. Springer, Cham. https://doi.org/10.1007/978-3-030-63505-3_2.

Setyawan, H. (2019). Blended Method: Online-Offline Teaching And Learning, On Students' Reading Achievement. English Education Jurnal Tadris Bahasa Inggris, 12(1), 22-33. https://doi.org/10.24042/ee-jtbi.v12i1.4432

Smidt, W. (2015). Educational Processes in Early Childhood Education: Activities of Target Children in Preschools. In: Schnotz W., Kauertz A., Ludwig H., Müller A., Pretsch J. (eds) Multidisciplinary Research on Teaching and Learning. Palgrave Macmillan, London. https://doi.org/10.1057/9781137467744__1

Smit, R. \& Engeli, E. (2015). An empirical model of mixed-age teaching. International Journal of Educational Research, 74, June 2015. DOI: 10.1016/j.ijer.2015.05.004

Sun, M. (2020). On the "Online and Offline" Hybrid Teaching Mode of College English. Conference: International Conference on Mental Health and Humanities Education (ICMHHE 2020), January 2020. DOI: 10.2991/assehr.k.200425.021

Szeto, E., \& Cheng, A. Y. N. (2016). Towards a framework of interactions in a blended synchronous learning environment: What effects are there on students' social presence experience? Interactive Learning Environments, 24(3), 487-503. https://doi.org/10.1080/10494820.2014.881391

Thota, Neena \& Negreiros, Joao G M, (2015). Introducing Educational Technologies to Teachers: Experience Report. Journal of University Teaching \& Learning Practice, 12(1). Available at: https://ro.uow.edu.au/jutlp/vol12/iss1/5

Torraco, R. J. (2005). Writing integrative literature reviews: Guidelines and examples. Human Resource Development Review, 4(3), 356-367. DOI: https://doi.org/10.1177/1534484305278283.

Vygotsky, L. (1934/1962). Thought and Language. Cambridge. MS: MIT Press. 
White, C.P., Ramirez, R., Smith, J.G., \& Plonowski, L. (2010). Simultaneous Delivery of a Face-to-Face Course to On-Campus and Remote Off-Campus Students. Techtrends Tech Trends, 54, 34-40 (2010). https://doi.org/10.1007/s11528-010-0418-Z

Xie, R. (2020). Research on the Mixed Teaching Mode of Higher Vocational Colleges Based on MOOC-In the Case of "Network Marketing" Course. 5th International Conference on Education and Social Development (ICESD 2020).

Zakirova, V.G., Grigoryeva, S.G., \& Kayumova, L.R. (2018). Theory of education. Kazan: Kazan University.

Zaščerinska, J. (2009). Information and Communication Technology within English for Academic Purposes Studies. Journal of Research in Pedagogy and Psychology SIGNUM TEMPORIS (2009) Volume 2, Number 1, September, 2009, pp. 131-138. Riga: Riga Teacher Training and Educational Management Academy, Latvia.

Zaščerinska, J. (2011). Social dimension of Web 3.0 in Engineering Education. In O. Bassus, A. Ahrens, \& C. Lange, (Ed.), Information and communication Technologies in Engineering and Business, pp. 101-130. Berlin: Mensch \& Buch.

Zaščerinska, J. (2013). Development of Students' Communicative Competence within English for Academic Purposes Studies. Verlag: Mensch \& Buch.

Zaščerinska, J., \& Ahrens, A. (2013). E-business Applications to Students' Blended Learning in Higher Education. In Mohammad S. Obaidat, Jose Luis Sevillano, Zhaoyang Zhang, Dacid Marca, Marca van Sinderek, Panagiotis Sarigiannidis, Piero Castoldi and Victor Torres-Padrosa (Eds), Proceedings of the 4th International Conference on Data Communication Networking (DC NET 2013), 10th International Conference on $e$ Business (ICE-B 2013) and 4th International Conference on Optical Communication Systems (OPTICS 2013), Reykjavik, Iceland, 29-31 July 2013, pp. 290-297. Publisher: SciTePress - Science and Technology Publications. Printed in Portugal.

Zaščerinska, J., Ahrens, A., \& Bassus, O. (2015). Effectiveness of Empirical Analysis of EBusiness Application: An Approach to Sampling in Educational Research. Proceedings of the 8th International Conference on Engineering and Business Education 8-9 October 2015, Østfold University College, Fredrikstad, Norway, 104-109. Published by University of Wismar, Germany.

Zascerinska, J., Aleksejeva, L., Zascerinskis, M., Gukovica, O., \& Aleksejeva, A. (2020). The Impact of COVID-19 on the Improvement of Teaching Skills on Problem-Solving Learning. International Journal for 21st Century Education (IJ21CE), Volumen 7, Número 1 (2020), pp. 42-59. DOI: 0.21071/ij21ce.v7i1.13074.

Zaščerinska, J., Zaščerinskis, M., Andreeva, N., Aḷeksejeva, L. (2013). Factors that Influence the Educational process. International Journal of Modern Education Forum (IJMEF) Volume 2, Issue 3 (August 2013), pp. 57-65. http://www.ijmef.org/AllIssues.aspx.

Zogla, I. (2018). Science of Pedagogy: Theory of Educational Discipline and Practice. Journal of Teacher Education for Sustainability, v20, n2 p31-43 2018.

Zogla, I. \& Lubkina, V. (2020). Doctoral Student's Research Competence. Education Content Research and Implementation Problems, Volume 1, 42-55.

https://doi.org/10.17770/er2020.1.5317

Zydney, J. M., McKimm, P., Lindberg, R., \& Schmidt, M. (2019). Here or there instruction: Lessons learned in implementing innovative approaches to blended synchronous learning. Tech Trends, 63, 123-132 https://doi.org/10.1007/s11528-018-0344-Z 